Article

\title{
From the Perspective of Battery Production: Energy-Environment-Economy (3E) Analysis of Lithium-Ion Batteries in China
}

\author{
Yixuan Wang ${ }^{1,2,3,4}$, Yajuan Yu ${ }^{2, *}$, Kai Huang ${ }^{5}$ and Baojun Tang $1,3,4,6,7$ \\ 1 Center for Energy and Environmental Policy Research, Beijing Institute of Technology, Beijing 100081, China; \\ yx_wang_ceep@163.com (Y.W.); tbj@bit.edu.cn (B.T.) \\ 2 School of Materials Science \& Engineering, Beijing Institute of Technology, Beijing 100081, China \\ 3 School of Management and Economics, Beijing Institute of Technology, Beijing 100081, China \\ 4 Beijing Key Lab of Energy Economics and Environmental Management, Beijing 100081, China \\ 5 College of Environmental Science and Engineering, Beijing Forestry University, Beijing 100083, China; \\ huangkai@bjfu.edu.cn \\ 6 Sustainable Development Research Institute for Economy and Society of Beijing, Beijing 100081, China \\ 7 Collaborative Innovation Center of Electric Vehicles in Beijing, Beijing 100081, China \\ * Correspondence: 04575@bit.edu.cn
}

Received: 23 September 2019; Accepted: 3 December 2019; Published: 5 December 2019

check for updates

\begin{abstract}
With the wide use of lithium-ion batteries (LIBs), battery production has caused many problems, such as energy consumption and pollutant emissions. Although the life-cycle impacts of LIBs have been analyzed worldwide, the production phase has not been separately studied yet, especially in China. Therefore, this research focuses on the impacts of battery production and builds an energy-environment-economy (3E) evaluation system. Two battery factories in China were selected for an applied research. Case 1 annually produces $0.22 \mathrm{GWh}$ lithium iron phosphate (LFP) batteries, while case 2 produces 0.024 GWh lithium nickel manganese cobalt oxide (NCM) batteries. The results demonstrate that electricity consumption per GWh LIBs production is $5.24 \times 10^{4}$ and $4.13 \times 10^{4} \mathrm{kWh}$ for case 1 and 2, respectively. Major water pollutant emissions come from employees' lives, and domestic waste accounts for $82 \%-83 \%$ of the total waste. Material costs per GWh NCM battery are $2.77 \times 10^{5}$ yuan, which is more expensive than the LFP battery, whose cathode material is relatively cheaper. Moreover, the cradle-to-gate carbon footprints (CFs) of the GWh LIBs are 41392.17 and $32254.57 \mathrm{~kg} \mathrm{CO}$ eq. The lithium compounds are major contributors to carbon emission for two LIBs. Some measures such as cleaner production, scale expansion and increase of environmental protection investment can effectively promote the development of a $3 \mathrm{E}$ system for LIB factories.
\end{abstract}

Keywords: lithium-ion battery; battery production; 3E analysis; life-cycle assessment; carbon footprint

\section{Introduction}

As an important technical product that can effectively relieve the pressure of energy and environment, the green secondary battery, especially lithium-ion battery (LIB), has developed rapidly [1] Because of long life, excellent performance and environmental benefits, LIBs have been widely applied in the consumer electronics and new energy vehicles since the products were introduced to market in 1991 [2-5]. As the major consumer of electric vehicles, China greatly encourages the development of the LIB industry and produces more than half the LIBs in the world. By now, China is donating in the LIB market.

However, the mass production of LIBs forces us to seriously think about the energy consumption and environmental issues. Lots of studies have shown that there are still many challenges in battery 
production [6,7]. In China, great efforts are needed to reduce greenhouse gas (GHG) emissions and improve environmental impacts from battery manufacturing [8]. For example, when $\mathrm{CO}_{2}$ emissions are significantly large during the battery production phase, the life-cycle $\mathrm{CO}_{2}$ emissions of battery electric vehicles tend to be bigger than that of internal combustion engine vehicles [9]. Although there are plenty of studies on these impacts of LIBs from the aspect of life cycle, it is still lack of the study focusing only on the battery production stage until now. In addition, it is very essential to research the LIB industry to make battery producers know the environmental loads of battery production and learn how to prevent some risks.

With the improvement of sustainability awareness, sustainable development of LIBs should focus on many aspects equally, such as energy, environment and economy. It is also necessary to think about the relationship of energy-environment-economy (3E) systems for green products. Though many scholars have conducted some studies focusing on 3E system for other products, there is no relative 3E analysis of LIBs. To evaluate the LIB production comprehensively, an evaluation system is constructed to analyze the $3 \mathrm{E}$ system for battery production and applied to Chinese battery factories.

\section{Literature Review}

LIBs have been gradually incorporated into the Environmental Assessment System with the improvement of a series of environmental standards. More and more studies concern battery's environmental performances and environmental risks. Life-cycle assessment (LCA) is an effective tool that considers overall environmental impacts from the aspect of life cycle and is widely used in comparing different products or technologies [10]. As an important means of environmental management, LCA has a unified international standard and diversified evaluation method system [11]. Allen and Steele proposed the LCA method for electric vehicle batteries in 1998, which provided a corresponding research basis for the LCA of other LIBs. More researchers started using this method to assess the life-cycle environmental impacts of LIBs. Some constructed inventories of different LIBs based on original data and compared the life-cycle impacts [12-14]. Others assessed the environmental impacts of LIBs at different boundaries, including cradle-to-gate, cradle-to-grave and grave-to-cradle [15]. Taking the assembly stage of low-output battery factory as an example, Dunn conducted a cradle-to-gate impact analysis on energy consumption and environmental loads [16]. Though battery production is the focus of these LCA studies due to the high energy consumption and environmental pollution, there is no comprehensive research only focusing on this phase and considering more research indicators, such as footprints. The footprint family is rarely used in LIB research, which refers to the carbon emissions and other impacts relating to human activities, including carbon footprint, water footprint and ecological footprint [17].

Considering that LCA is a method of environmental management involving energy and material flow, scholars usually use it to evaluate the energy and environment systems for research products. However, it is also necessary to think about other aspects and the relationship of 3E systems. Energy-environment-economy research is used to restrict either economic development from the view of environmental protection or the use of resources with economic means. At present, many developed countries have listed the research results of $3 \mathrm{E}$ into their long-term development plans. Moreover, many scholars have done lots of work from different research perspectives. Lenzen selected a series of indicators of energy, environment and economy to analyze the 3E system of Australia [18]. Lazzaretto used the method of system analysis to evaluate the 3E system and estimate the treatment cost generated by industrial emissions [19]. Since the 1980s, China has also gradually formed a comprehensive research system of $3 \mathrm{E}$ to carry out more specific studies. However, a universal evaluation system that can unify the $3 \mathrm{E}$ system is needed to analyze the relationship of energy, environment and economy for LIBs.

To solve the above problems, this research constructs a relatively comprehensive $3 \mathrm{E}$ evaluation system and selects two typical battery factories in China for an applied research. In the results section, the research not only analyzes the 3E system's impacts of battery factories but also takes cradle-to-gate carbon footprints (CFs) of LIBs into account, which can provide a certain reference for the government and other battery factories. 


\section{Materials and Methods}

\subsection{Research Framework}

Overall, a 3E evaluation system of LIBs has been constructed to compare different battery production situations and LIB products. An applied research was conducted to analyze the general $3 \mathrm{E}$ development of the LIB industry in China. The research framework of the study is shown in Figure 1.

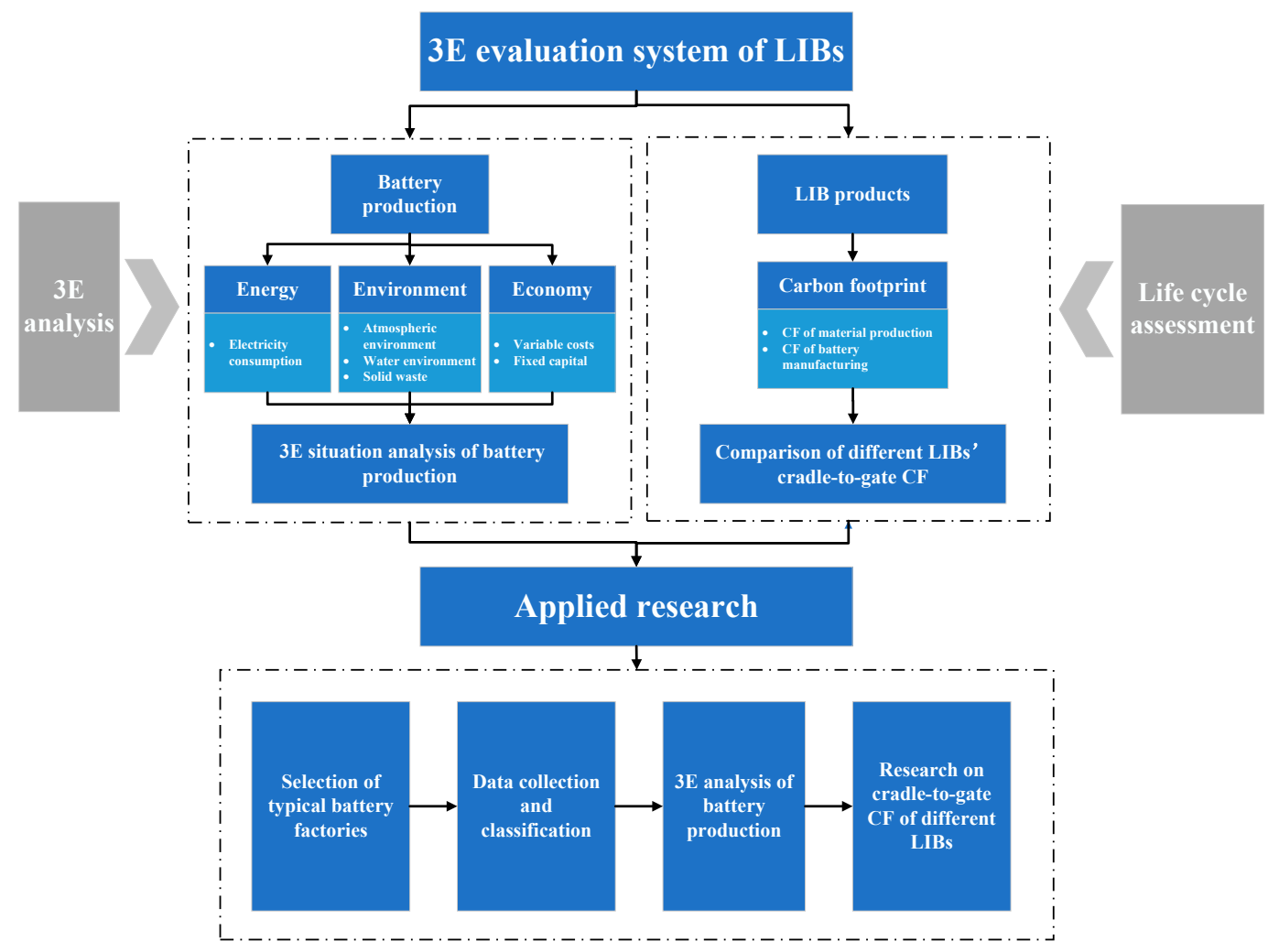

Figure 1. Framework.

Considering the importance of battery production and popularity of battery products, a $3 \mathrm{E}$ evaluation system of LIBs was built to analyze several impacts of LIBs. Firstly, 3E analysis was applied to research the $3 \mathrm{E}$ system in battery production. There are six categories of indicators being researched here in the energy, environment and economy systems. The energy and environment systems mainly contain the direct electricity consumption and pollutant emissions in actual battery production, while variable costs and fixed capital were selected as total production costs to research the economy system. Secondly, carbon emission is an extremely important topic of interest in climate change, and it is necessary to research the carbon footprints of different LIBs to choose more low-carbon products. Here the production of main raw materials and batteries' manufacturing processes were considered to compare cradle-to-gate CFs of different LIBs by LCA. CFs were calculated by the method of IPCC in SimaPro and the Greenhouse Gases, Regulated Emissions, and Energy Use in Transportation (GREET) Model.

Finally, typical Chinese battery factories were selected for applied research to evaluate the main 3E impacts in actual LIB production. Here considering that China's LIB industry is mainly distributed in the Pearl River Delta region, the factories of different scale in this region are used for comparison. In this part, the production data are mainly from the Environmental Impact Assessment reports of factories and actual production surveys, while the list of raw materials is from the industry production in two battery factories. After collecting, classifying and standardizing a large amount of data, a $3 \mathrm{E}$ evaluation of LIBs was conducted to compare different battery factories and LIB products. 


\subsection{Research Methods}

\subsubsection{E Analysis of Battery Production}

Energy-environment-economy analysis usually refers to the comprehensive evaluation of the processes from the aspects of the $3 \mathrm{E}$ system, including raw materials production, manufacturing, use and waste disposal. The research mainly focuses on the battery production stage, where 3E research indicators are based on the actual production situation. A relatively comprehensive indicator system was formed after the classification of various indicators, as shown in Figure 2.

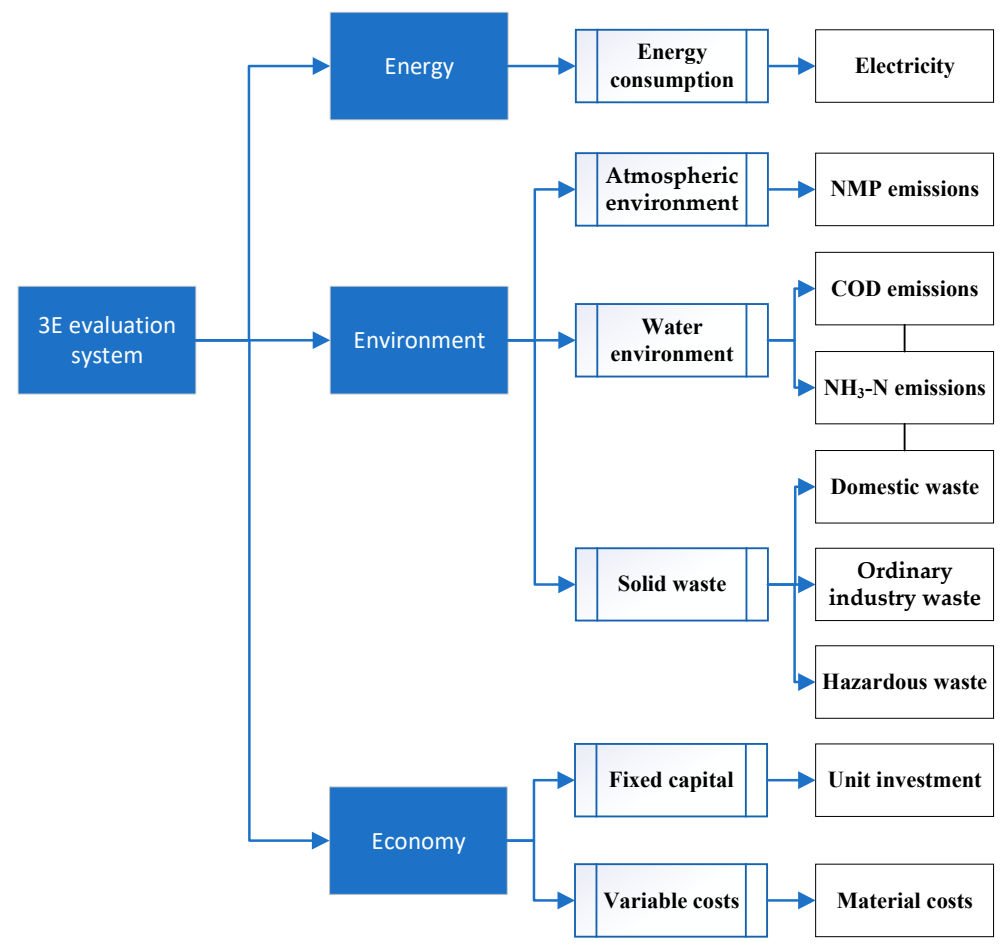

Figure 2. Indicator system.

In terms of energy system, the major energy consumption is electricity, which is used for equipment operation and auxiliary energy consumption of employees' lives. Atmospheric environment, water environment and solid waste were considered in the environment system, and there are six environmental pollutants, such as NMP gas. Because there are some similar production chains consisting of electrode production, cell production and cell conditioning in different battery factories, production processes are assumed to be the same for two cases in this research [20]. To compare different factories, $1 \mathrm{GWh}$ battery production was selected as the functional unit to perform the 3E analysis and LCA. The energy consumption or environmental impacts of battery production per GWh is represented by $E E$, which can be calculated by Equation (1). The data of annual electricity consumption or pollutant emissions are from actual production situations and are represented by $E_{e} . O$ is used to represent the annual output, whose unit is GWh.

$$
E E=E_{e} / O
$$

In the economy system, battery production costs are mainly considered and are divided into fixed capital and variable costs. Both equipment investment and construction costs belong to the fixed capital. The service life of equipment and facilities is assumed to be 10 years, while variable costs contain materials costs, labor costs and energy costs. Referring to the study of Berg, the proportion of battery material costs in battery production is about $75 \%$ [21], so materials costs are analyzed emphatically in this research. The materials' price comes from the market research and is assumed to be inelastic. At the same time, the indicators such as building area and number of employees are also compared to learn whether there are certain scale effects under different scale of factories. 


\subsubsection{Life-Cycle Assessment of LIB Products}

LCA is a kind of typical tool that can analyze the characteristics of a product, which can be used to research the whole life-cycle processes including raw materials production, manufacturing, use and final disposition. The International Organization for Standardization (ISO) states that LCA can be divided into four phases: Goal and scope definition, inventory analysis, impact assessment and interpretation [22]. As a bottom-up calculation method, LCA has been widely used in micro-analysis. With the wide use of LCA, a lot of software (e.g., SimaPro, Umberto) with various databases and calculation methods is developed around world. In this research, LCA was used to analyze the environmental impacts of different LIB products. The research boundary is from cradle to gate, which mainly contains the processes of materials production and battery manufacturing. In both processes, there are some input flows of raw materials and energy, and some by-products and pollutions are discharged in the production of target products, as shown in Figure 3.

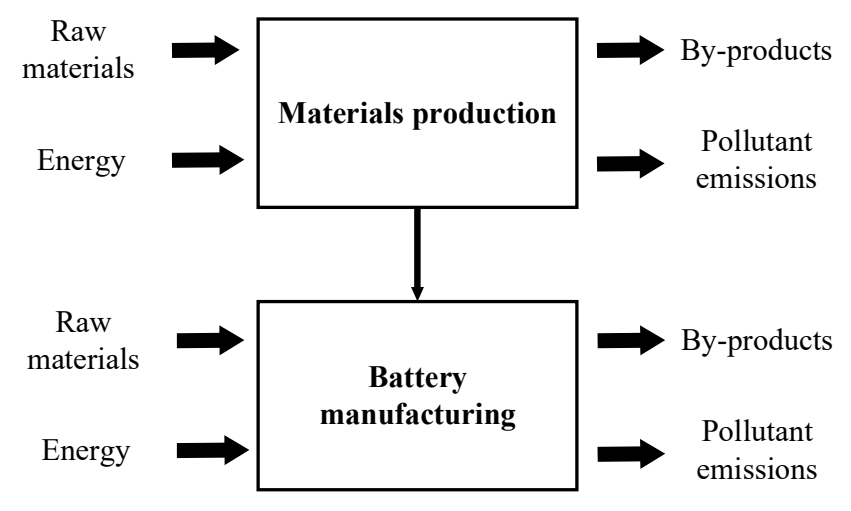

Figure 3. Lithium-ion battery (LIB) production.

The functional unit of LCA is $1 \mathrm{GWh}$ battery production, and CF is selected as the impact indicator. $\mathrm{CF}$ is a kind of measurement of carbon emission and has been recognized by many international communities, which is mainly used for the assessment of environmental impacts caused by human activities [23]. Carbon dioxide equivalent $\left(\mathrm{CO}_{2} \mathrm{eq}\right)$ is usually used to represent $\mathrm{CF}$ and is equal to the amount of direct and indirect GHG emissions. Here $C F_{m a t}$ stands for the $C F$ of materials production and is calculated by the method of IPCC in SimaPro, as shown in Equation (2). Suppose there are $m$ kinds of materials used for $1 \mathrm{GWh}$ battery production, and the mass of required material $n$ is $M_{n}$. $E F_{n}$ is the CF from the production of $1 \mathrm{~kg}$ material, $n$.

$$
C F_{\text {mat }}=\sum_{n=1}^{m} M_{n} \times E F_{n}
$$

Considering that there are few direct GHG emissions in battery production, indirect GHG emissions from the production of consumed energy are regarded as the CF of battery manufacturing. Electricity is the major energy consumption to consider in battery production, and the CF of its production can be calculated by the Greenhouse Gases, Regulated Emissions, and Energy Use in Transportation (GREET) Model to represent the CF of battery manufacturing.

\subsection{Applied Research}

Two battery factories in China were chosen as the research cases and named case 1 and case 2 . Case 1 produces 0.22 GWh LIBs each year whose main products are LFP batteries. The LFP battery is a kind of LIB whose positive active material is $\mathrm{LiFePO}_{4}$, while case 2 annually produces $0.024 \mathrm{GWh}$ NCM batteries. The positive active material of $\mathrm{NCM}$ battery is $\mathrm{Li}\left(\mathrm{Ni}_{\mathrm{x}} \mathrm{Co}_{\mathrm{y}} \mathrm{Mn}_{1-\mathrm{x}-\mathrm{y}}\right) \mathrm{O}_{2}$. Major differences between the two batteries are cathode materials and the input ratio of battery components. Meanwhile, case 1 has 462 employees and covers the area of $32015 \mathrm{~m}^{2}$, while the case 2 has only 100 employees and 
covers the area of $1686 \mathrm{~m}^{2}$. Detailed situations of cases 1 and 2 are shown in Figure 4 to illustrate the 3 E system of two factories vividly.

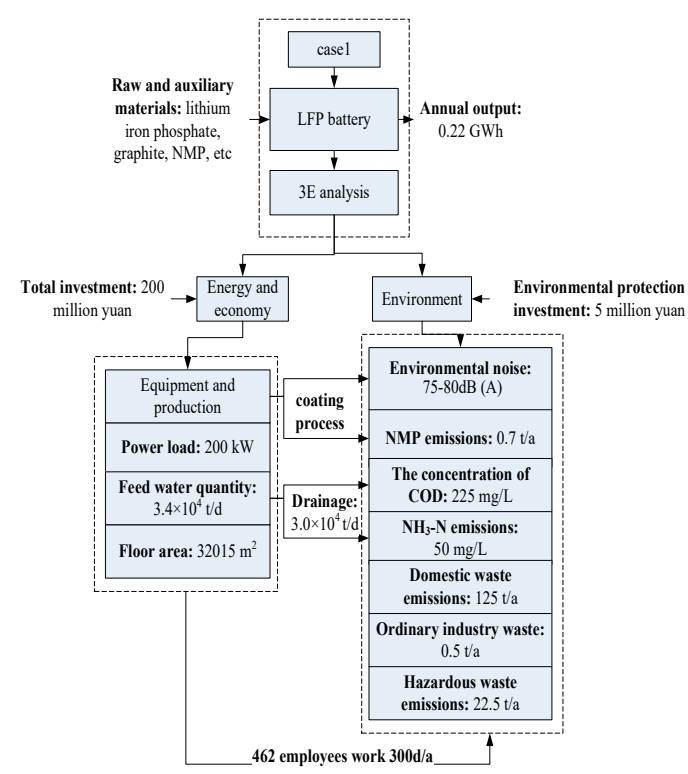

(a)

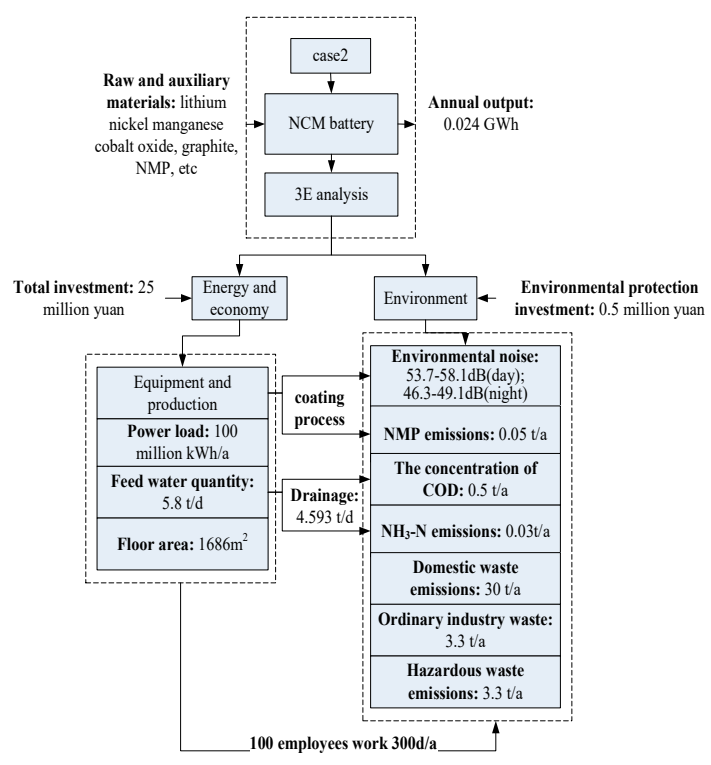

(b)

Figure 4. Energy-environment-economy (3E) situations of two factories. (a) 3E situations of case 1; (b) $3 \mathrm{E}$ situations of case 2 .

For LIBs, there are five main components to make one battery, including positive electrode, negative electrode, electrolyte, separator and housing. For different batteries, the proportion of components and materials added is not exactly the same. To make the LIB products consistent with the actual battery production situation in $3 \mathrm{E}$ analysis, the mass of main battery materials consumed annually is based on the actual production inputs from the Environmental Impact Assessment reports of two factories, as shown in Table 1. The research also assumed that the losses in battery production are negligible.

Table 1. The list of main materials in battery production.

\begin{tabular}{ccc}
\hline Name of the Material & $\begin{array}{c}\text { Lithium Iron Phosphate } \\
\text { (LFP) Battery of Case 1(t) }\end{array}$ & $\begin{array}{c}\text { Nickel Manganese Cobalt Oxide } \\
\text { (NCM) Battery of Case 2(t) }\end{array}$ \\
\hline NMP & 70 & 10 \\
Lithium iron phosphate & 200 & 0 \\
Lithium nickel manganese cobalt oxide & 0 & 30 \\
Graphite & 94 & 13 \\
Copper foil & 74 & 8 \\
Aluminum foil & 45.7 & 5 \\
Nickel strip & 5.5 & 1 \\
Separator & 161.07 & 18.2 \\
\hline
\end{tabular}

\section{Results and Discussion}

\subsection{E Analysis of Battery Production}

According to the system of $3 \mathrm{E}$ indicators, nine indicators of $3 \mathrm{E}$ system in battery production were obtained and calculated by industry survey. The specific indexes and calculation results are shown in Table 2. 
Table 2. 3E impacts of battery production per GWh.

\begin{tabular}{|c|c|c|c|c|c|c|c|c|c|}
\hline \multirow{2}{*}{\begin{tabular}{|l} 
System \\
Category \\
Indicator
\end{tabular}} & \multirow{2}{*}{$\begin{array}{c}\text { Energy } \\
\begin{array}{c}\text { Energy } \\
\text { Consumption }\end{array} \\
\text { Electricity } \\
\end{array}$} & \multicolumn{6}{|c|}{ Environment } & \multicolumn{2}{|c|}{ Economy } \\
\hline & & $\begin{array}{c}\text { Atmospheric } \\
\text { Environment } \\
\text { NMP }\end{array}$ & \multicolumn{2}{|c|}{$\begin{array}{c}\text { Water } \\
\text { Environment }\end{array}$} & \multicolumn{3}{|c|}{ Solid Waste } & $\begin{array}{c}\begin{array}{c}\text { Variable } \\
\text { Costs }\end{array} \\
\text { Material } \\
\text { costs }\end{array}$ & $\begin{array}{c}\begin{array}{c}\text { Fixed } \\
\text { Capital }\end{array} \\
\begin{array}{c}\text { Unit } \\
\text { investment }\end{array}\end{array}$ \\
\hline Unit & $\mathrm{kWh}$ & $\mathrm{kg}$ & $\mathrm{kg}$ & $\mathrm{kg}$ & $\mathrm{kg}$ & $\mathrm{kg}$ & $\mathrm{kg}$ & yuan & yuan \\
\hline Case 1 & $5.24 \times 10^{4}$ & 2.95 & 29.45 & 6.95 & 559.64 & 2.45 & 114.87 & $1.56 \times 10^{5}$ & $9.10 \times 10^{7}$ \\
\hline
\end{tabular}

The electricity consumption of battery production per GWh is $5.24 \times 10^{4}$ and $4.13 \times 10^{4} \mathrm{kWh}$ for case 1 and 2, respectively. Though case 1 owns more production equipment, employees and investment than case 2 , it did not save some to some extent. In aspects of air and water environment, the emissions of NMP, $\mathrm{NH}_{3}-\mathrm{N}$ and COD were considered. NMP gas is mainly from the evaporation of the NMP solvent in coating process and is relevant to the input ratio of battery materials, while COD and $\mathrm{NH}_{3}-\mathrm{N}$ are mainly from the domestic water discharged by employees' lives. For these pollutants, the emissions of case 2 are $84.8 \%, 63.7 \%$ and $18.0 \%$ of case 1 . The reason why case 1 produces more air and water pollutants is that more NMP is used in the production of LFP batteries, and lots of employees use more water in their lives. For solid wastes, the domestic waste is 559.64 and $1260.00 \mathrm{~kg}$ for case 1 and 2 , respectively, which is mainly from staff life and disposed of by the relative sanitation department. Ordinary industry waste is extremely scarce in case 1, which shows that case 1's disposal of industrial waste is more reasonable. Moreover, the two factories produced $17.0 \%$ and $8.9 \%$ hazardous waste, which consists of the waste materials and solvent in battery production. Hazardous waste must be processed reasonably by qualified companies or it will have a significant environmental impact in the future.

The factories spend $1.56 \times 10^{5}$ and $2.77 \times 10^{5}$ yuan for case 1 and 2, respectively, on the materials when they produce $1 \mathrm{GWh}$ batteries, which is extremely related to the type of LIB. The production of NCM battery usually uses more expensive materials, such as cobalt and other metals. As for the capital investment, the costs are $9.10 \times 10^{7}$ and $10.42 \times 10^{7}$ yuan/GWh for case 1 and case2, respectively. Though the scale of case 2 is far less than case 1 from the aspects of building area, number of employees and total investments, the costs of it are higher than case 1. The relationship between unit scale investment and environment protection investment shows that the two plants hold the same view on environmental protection. The proportion of green investment is $2.52 \%$ and $2.04 \%$ for case 1 and 2 , respectively.

\subsection{Research on the Relationship of 3E Systems}

The relationship of different indicators in energy, environment and economy systems was also learned to think about how to improve the coordinated development of the $3 \mathrm{E}$ system. At first, pollutant emissions and costs based on unit electricity consumption were calculated to compare the situations of energy use in two factories, as shown in Table 3.

Table 3. Pollutant emissions and costs based on unit electricity consumption.

\begin{tabular}{lcccccccc}
\hline & NMP (kg) & COD $(\mathbf{k g})$ & $\begin{array}{c}\mathbf{N H}_{3}-\mathbf{N} \\
\mathbf{( k g}\end{array}$ & $\begin{array}{c}\text { Household } \\
\text { Waste (kg) }\end{array}$ & $\begin{array}{c}\text { Ordinary } \\
\text { Industry } \\
\text { Waste (kg) }\end{array}$ & $\begin{array}{c}\text { Hazardous } \\
\text { Waste (kg) }\end{array}$ & $\begin{array}{c}\text { Material } \\
\text { Costs } \\
\text { (yuan) }\end{array}$ & $\begin{array}{c}\text { Unit } \\
\text { Investment } \\
\text { (yuan) }\end{array}$ \\
\hline Case 1 & $5.62 \times 10^{-5}$ & $5.62 \times 10^{-4}$ & $1.33 \times 10^{-4}$ & $1.07 \times 10^{-2}$ & $4.69 \times 10^{-5}$ & $2.19 \times 10^{-3}$ & 2.99 & $1.74 \times 10^{3}$ \\
Case 2 & $6.06 \times 10^{-5}$ & $4.55 \times 10^{-4}$ & $3.03 \times 10^{-5}$ & $3.05 \times 10^{-2}$ & $3.36 \times 10^{-3}$ & $3.31 \times 10^{-3}$ & 6.72 & $2.54 \times 10^{3}$ \\
\hline
\end{tabular}

The results are shown in Figure 5. The "+" represents that the relative impact results for this case are greater than the other, while " $-"$ " stands for the opposite. It reveals that the four impact results for case 1 are $92.87 \%, 143.36 \%, 34.75 \%$ and $68.70 \%$ of case 2 . Except for water pollution, most of the environmental impacts and costs are smaller for case 1 , which shows that case 1 use energy more 
reasonably. As for water pollution, the number of employees required for unit battery production may be the biggest reason for the high emissions of $\mathrm{NH}_{3}-\mathrm{N}$ and COD in case 1, which also indicates that the environmental awareness of staff is not strong enough, while case 2 pays less attention to the solid waste, which cannot be disposed reasonably. Domestic waste accounts for $82 \%-83 \%$ of the total waste and is the major contributor to solid waste for two factories. Case 2 also spends more money on material costs, which is caused by the high prices of raw materials for the NCM battery. Therefore, there seems to be some scale effects between two factories from the view of 3E analysis. Scale expansion of factories may be one of ways of improving the environmental impacts and reducing the production costs for battery factories.

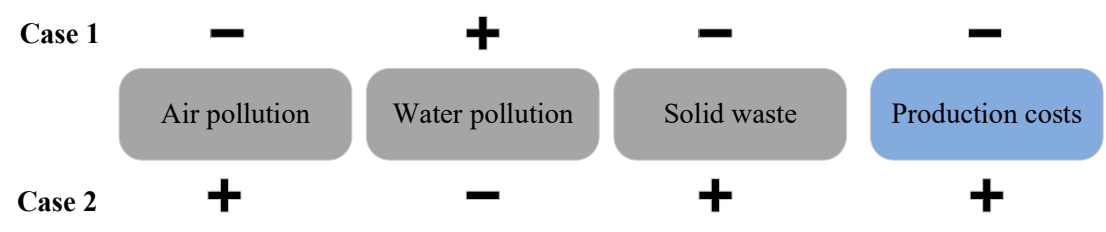

Figure 5. Environmental impacts and costs of unit energy use.

In addition, the economic analysis was also carried out to compare the 3E system for two battery factories. Energy consumption and pollutant emissions based on unit costs have been calculated to compare the capital utilization, as shown in Table 4. The results of the comparison are shown in Figure 6.

Table 4. Consumption and pollutant emissions based on unit costs.

\begin{tabular}{cccccccc}
\hline & $\begin{array}{c}\text { Electricity } \\
\mathbf{( k W h})\end{array}$ & NMP (kg) & COD $(\mathbf{k g})$ & $\begin{array}{c}\mathbf{N H}_{3}-\mathbf{N} \\
\mathbf{( k g})\end{array}$ & $\begin{array}{l}\text { Household } \\
\text { Waste } \mathbf{( k g})\end{array}$ & $\begin{array}{c}\text { Ordinary Industry } \\
\text { Waste }(\mathbf{k g})\end{array}$ & $\begin{array}{c}\text { Hazardous } \\
\text { Waste }\end{array}$ \\
\hline Case 1 & $5.75 \times 10^{-4}$ & $3.23 \times 10^{-8}$ & $3.23 \times 10^{-7}$ & $7.63 \times 10^{-8}$ & $6.15 \times 10^{-6}$ & $2.69 \times 10^{-8}$ & $1.26 \times 10^{-6}$ \\
Case 2 & $3.95 \times 10^{-4}$ & $2.39 \times 10^{-8}$ & $1.80 \times 10^{-7}$ & $1.20 \times 10^{-8}$ & $1.21 \times 10^{-5}$ & $1.33 \times 10^{-6}$ & $1.31 \times 10^{-6}$ \\
\hline
\end{tabular}

Case 1

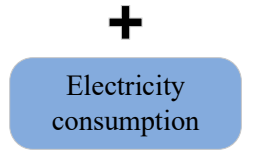

Case 2
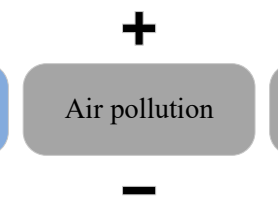

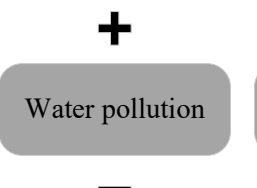

Solid waste

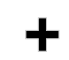

Figure 6. Energy consumption and environmental impacts of unit costs.

The four impact results for case 1 are $145.56 \%, 135.18 \%, 208.67 \%$ and $50.58 \%$ of case 2 . Except for solid waste, most of the impact results are bigger for case 1, which reveals that the use of funds is not reasonable and unit capital input causes greater impacts on the energy and environment in case 1 . To improve $3 \mathrm{E}$ development for battery factories, more capital should be inputted to the construction of environmental protection facilities and energy-saving facilities.

\subsection{Life-Cycle Assessment of LIB Product}

The processes of materials production and battery manufacturing are considered to compare the cradle-to-gate carbon emissions of different LIBs. The results are shown in Figure 7.

The total CF of raw materials production is 1599.08 and $894.57 \mathrm{~kg} \mathrm{CO}_{2} \mathrm{eq}$ for case 1 and 2, respectively, when producing $1 \mathrm{GWh}$ batteries. The $\mathrm{CF}$ of lithium compounds is extremely high compared to other materials for the two batteries, which is 785.97 and $715.45 \mathrm{~kg} \mathrm{CO}_{2}$ eq. Due to the scarcity of lithium as a resource, the acquisition of it requires greatly complicated processes with lots of GHG emissions. The CFs of separator and graphite are also higher than other materials because of 
the high consumption in actual production. The CF percentage charts were drawn to reveal the main contributory material for GHG emissions, as shown in Figure 8.

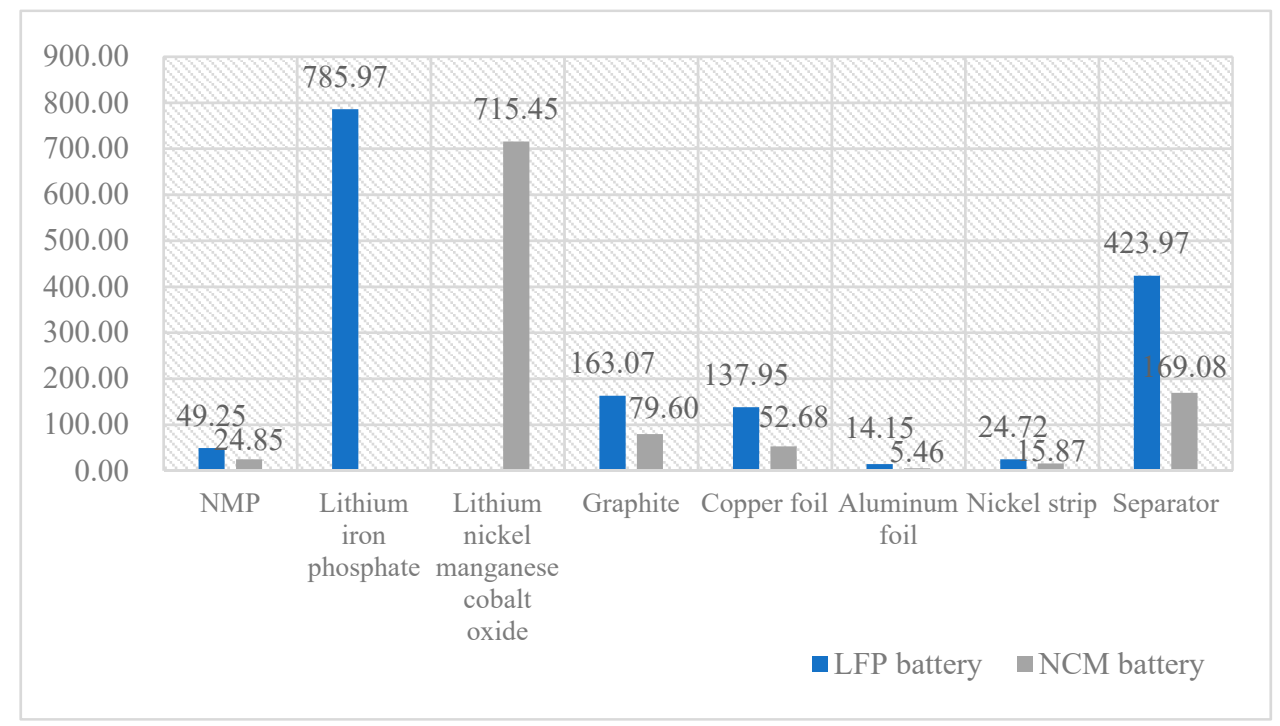

Figure 7. Carbon footprint (CF) values of raw materials.

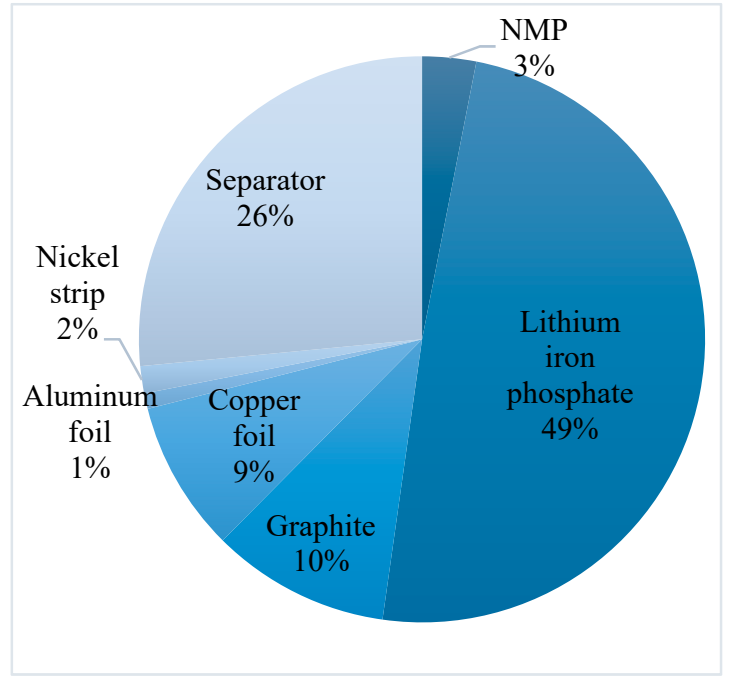

(a)

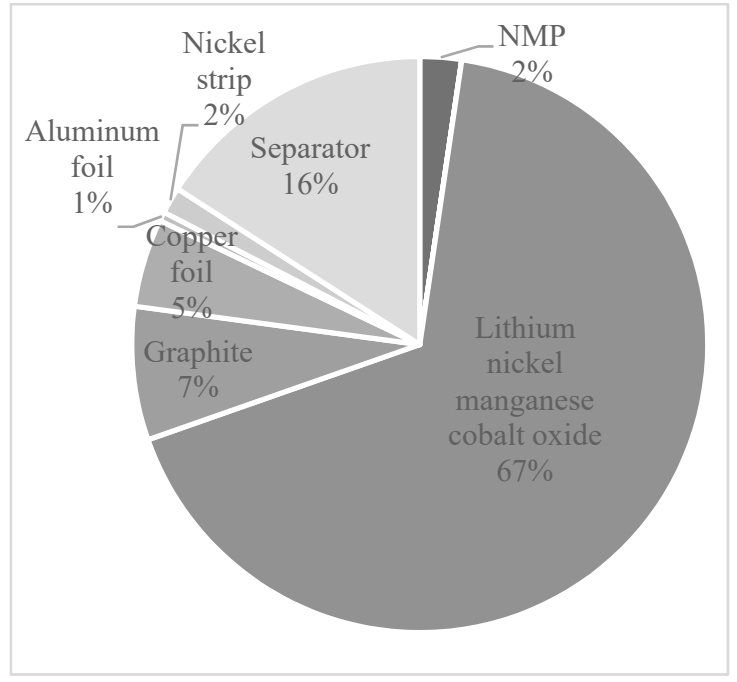

(b)

Figure 8. CF percentage of raw materials. (a) LFP battery (b) NCM battery.

The CF of LFP material is nearly half the total CF for LFP battery, which is related to the input ratio of lithium compound and high carbon emissions of LFP production. The CF of separator accounts for $26 \%$, while the CF of copper material and graphite account for $9 \%$ and $10 \%$, respectively. For the NCM battery, the proportion of CF of lithium material is $67 \%$, and the second biggest contributor is separator, whose proportion is $16 \%$. The CF of copper material and graphite only account for $5 \%$ and $7 \%$, respectively. In actual production, the $\mathrm{CF}$ of materials production may be very different because the material input and utilization situation are not exactly same, but effective measures should be taken to reduce the $\mathrm{CF}$ from the perspective of using more low-carbon materials and decreasing the carbon emissions of necessary materials' production for all the battery factories. 
During the battery manufacturing process, the emissions from the electricity production is mainly considered because there are no direct carbon emissions. Referring to China's power generation scenario in the GREET model, the carbon emissions in battery production can be available. The results show that the $\mathrm{CF}$ of battery manufacturing is $39,793.09$ and $31,360.00 \mathrm{~kg} \mathrm{CO} \mathrm{CO}_{2}$ eq. Based on above results, the total cradle-to-gate carbon emissions of LFP battery production per GWh is $41,392.17 \mathrm{~kg} \mathrm{CO}_{2} \mathrm{eq}$, while the NCM battery's is $32,254.57 \mathrm{~kg} \mathrm{CO}_{2}$ eq. As a result, the battery manufacturing stage is the major contributor to carbon emissions. The battery factories should take some steps to reduce the GHG emissions by consuming less power in production. For China, it is very necessary to implement the low-carbon electricity production and use more renewable energy in power generation.

\section{Conclusions}

To evaluate the production of LIB products comprehensively, an evaluation system was built to analyze the relationship of energy, environment and economy systems. As the major producer of LIBs, China was selected for an applied research by comparing different battery factories and LIBs. Based on above research results, the following conclusions are drawn:

(1) In the phase of LIB production, the electricity consumption of battery production per GWh in two factories is $5.24 \times 10^{4}$ and $4.13 \times 10^{4} \mathrm{kWh}$. Major water pollutant emissions come from employees' lives, and domestic waste accounts for $82 \%-83 \%$ of the total waste. The improvement of staff's sustainable awareness is extremely necessary in reducing the environmental pollution in battery production. Material costs of NCM battery are $2.77 \times 10^{5}$ yuan/GWh, and it is more expensive than the LFP battery, whose cathode material is relatively cheaper. For battery production factories, it is very important to reduce the battery production costs and enhance its environmental quality by implementing cleaner production.

(2) In the research on relationship of 3E systems, case 1 performs better in pollutant emissions and costs based on unit electricity consumption. There are some scale effects between the two factories, which shows that scale expansion of battery factory may be one of the ways of improving the environmental impact and reducing costs. However, when considering energy consumption and pollutant emissions based on unit costs, most of the impacts are bigger for case 1, which does not utilize funds well. To improve $3 \mathrm{E}$ development for battery factories, more capital should be put into the construction of environmental protection facilities and energy-saving facilities.

(3) The cradle-to-gate CF of the two batteries is 41392.17 and $32254.57 \mathrm{~kg} \mathrm{CO}_{2}$ eq when producing 1 GWh batteries, which is related to carbon emissions in the production of raw materials and electricity. The $\mathrm{CF}$ of lithium compounds and separator are extremely high compared to other materials for two LIBs. Using low-carbon materials and reducing the GHG emissions in materials production are efficient paths to decrease the $\mathrm{CF}$ of materials production. Moreover, the battery manufacturing stage is the major contributor to carbon emissions. It is very necessary to implement the low-carbon electricity production and use more renewable energy in power generation.

Considering some limits of $3 \mathrm{E}$ analysis itself and difference of battery indicators, the research still cannot evaluate the impacts of $3 \mathrm{E}$ system in battery production roundly. It is hoped that more scholars will carry out in-depth 3E research on LIBs in the future.

Author Contributions: Y.Y. conceived and designed the study; Y.W. analyzed the data and wrote the paper; K.H. B.T. helped to revise the manuscript.

Funding: This research was funded by [1] the National Natural Science Foundation of China [No. 51474033, 71934004, 71573013, 71521002, and 71642004]; [2] the Beijing Natural Science Foundation of China [No. 9172012, 9152014]; [3] the Special Items Fund for Cultivation and Development of Beijing Creative Base [Grant No. Z171100002217023]; [4] the Key Project of Beijing Social Science Foundation Research Base [Grant No. 15JDJGA084]; [5] the National Key R\&D Program [Grant No. 2016YFA0602603], and [6] the Special Items Fund of Beijing Municipal Commission of Education.

Conflicts of Interest: The authors declare no conflict of interest. 


\section{References}

1. Ordoñez, J.; Gago, E.J.; Girard, A. Processes and technologies for the recycling and recovery of spent lithium-ion batteries. Renew. Sustain. Energy Rev. 2016, 60, 195-205. [CrossRef]

2. Zhang, W.X.; Zhang, Y.M.; Yang, Z.H.; Chen, G.D.; Ma, G.; Wang, Q. In-situ design and construction of lithium-ion battery electrodes on metal substrates with enhanced performances: A brief review. Chin. J. Chem. Eng. 2016, 24, 48-52. [CrossRef]

3. Scrosati, B.; Garche, J. Lithium batteries: Status, prospects and future. J. Power Sources 2010, 195, $2419-2430$. [CrossRef]

4. Shi, X.; Wang, X.; Yang, J.; Sun, Z. Electric vehicle transformation in Beijing and the comparative eco-environmental impacts: A case study of electric and gasoline powered taxis. J. Clean. Prod. 2016, 137, 449-460. [CrossRef]

5. Zhang, G.; Du, Z.; He, Y.; Wang, H.; Xie, W.; Zhang, T. A Sustainable Process for the Recovery of Anode and Cathode Materials Derived from Spent Lithium-Ion Batteries. Sustainability 2019, 11, 2363. [CrossRef]

6. Etacheri, V.; Marom, R.; Elazari, R.; Salitra, G.; Aurbach, D. Challenges in the development of advanced Li-ion batteries: A review. Energy Environ. Sci. 2011, 4, 3243-3262. [CrossRef]

7. Manthiram, A. Materials Challenges and Opportunities of Lithium Ion Batteries. J. Phys. Chem. Lett. 2011, 2, 176-184. [CrossRef]

8. Hao, H.; Mu, Z.X.; Jiang, S.H.; Liu, Z.W.; Zhao, F.Q. GHG Emissions from the Production of Lithium-Ion Batteries for Electric Vehicles in China. Sustainability 2017, 9, 12. [CrossRef]

9. Kawamoto, R.; Mochizuki, H.; Moriguchi, Y.; Nakano, T.; Motohashi, M.; Sakai, Y.; Inaba, A. Estimation of CO2 Emissions of Internal Combustion Engine Vehicle and Battery Electric Vehicle Using LCA. Sustainability 2019, 11, 2690. [CrossRef]

10. Noori, M.; Kucukvar, M.; Tatari, O. Economic Input-Output Based Sustainability Analysis of Onshore and Offshore Wind Energy Systems. Int. J. Green Energy 2014, 12, 939-948. [CrossRef]

11. Asadi, S.; Babaizadeh, H.; Foster, N.; Broun, R. Environmental and economic life cycle assessment of PEX and copper plumbing systems: A case study. J. Clean. Prod. 2016, 137, 1228-1236. [CrossRef]

12. Sullivan, J.L.; Gaines, L. Status of life cycle inventories for batteries. Energy Convers. Manag. 2012, 58, $134-148$. [CrossRef]

13. Ellingsen, L.A.W.; Majeau-Bettez, G.; Singh, B.; Srivastava, A.K.; Valoen, L.O.; Stromman, A.H. Life Cycle Assessment of a Lithium-Ion Battery Vehicle Pack. J. Ind. Ecol. 2014, 18, 113-124. [CrossRef]

14. Majeau-Bettez, G.; Hawkins, T.R.; Stromman, A.H. Life cycle environmental assessment of lithium-ion and nickel metal hydride batteries for plug-in hybrid and battery electric vehicles. Environ. Sci. Technol. 2011, 45, 4548-4554. [CrossRef] [PubMed]

15. Zhang, X.X.; Li, L.; Fan, E.S.; Xue, Q.; Bian, Y.F.; Wu, F.; Chen, R.J. Toward sustainable and systematic recycling of spent rechargeable batteries. Chem. Soc. Rev. 2018, 47, 65. [CrossRef]

16. Dunn, J.B.; Gaines, L.; Kelly, J.C.; James, C.; Gallagher, K.G. The significance of Li-ion batteries in electric vehicle life-cycle energy and emissions and recycling's role in its reduction. Energy Environ. Sci. 2015, 8, 158-168. [CrossRef]

17. Yue Zhang, K.H.; Yu, Y.J.; Yang, B.B. Mapping of water footprint research: A bibliometric analysis during 2006-2015. J. Clean. Product. 2017, 149, 70-79. [CrossRef]

18. Lenzen, M.; Dey, C.J. Economic, energy and greenhouse emissions impacts of some consumer choice, technology and government outlay options. Energy Econ. 2002, 24, 377-403. [CrossRef]

19. Lazzaretto, A.; Toffolo, A.; Reini, M.; Taccani, R.; Zaleta-Aguilar, A.; Rangel-Hernandez, V.; Verda, V. Four approaches compared on the TADEUS (thermoeconomic approach to the diagnosis of energy utility systems) test case. Energy 2006, 31, 1586-1613. [CrossRef]

20. Kwade, A.; Haselrieder, W.; Leithoff, R.; Modlinger, A.; Dietrich, F.; Droeder, K. Current status and challenges for automotive battery production technologies. Nat. Energy 2018, 3, 290-300. [CrossRef]

21. Berg, H.; Zackrisson, M. Perspectives on environmental and cost assessment of lithium metal negative electrodes in electric vehicle traction batteries. J. Power Sources 2019, 415, 83-90. [CrossRef]

22. Yilmaz, O.; Anctil, A.; Karanfil, T. LCA as a decision support tool for evaluation of best available techniques (BATs) for cleaner production of iron casting. J. Clean. Prod. 2015, 105, 337-347. [CrossRef] 
23. Messerli, B.; Grosjean, M.; Hofer, T.; Nunez, L.; Pfister, C. From nature-dominated to human-dominated environmental changes. Quat. Sci. Rev. 2000, 19, 459-479. [CrossRef]

(C) 2019 by the authors. Licensee MDPI, Basel, Switzerland. This article is an open access article distributed under the terms and conditions of the Creative Commons Attribution (CC BY) license (http://creativecommons.org/licenses/by/4.0/). 